\title{
Re-imagining Shakespeare as our Contemporary- Alternate Interpretations of Hamlet in the theatrical space: Traversing from Local to Global and vice versa; an attempt at dismantling the canon or perpetuating its transience?
}

\section{Purbali Sengupta}

Faculty of French, International School of Hospitality Management, Kolkata, India.

Mail Id: purbali4042@gmail.com | ORCID ID: 0000-0002-7079-9204

\begin{abstract}
The very act of articulating Shakespeare from a space in the Global South can trigger a maelstrom of contesting ideologies. There was always a mad scramble among academics to interpret and own the bard intimately. Undoubtedly, one of the aspects of British colonial rule was to establish its cultural hegemony and 'Englishness' in the colonies through a well-designed curriculum. However, the colonial structures of power implicated into institutional fabrics make the task of a post-colonial scholar challenging the colonial ideology, quite complex. William Shakespeare, has (often anachronistically), traversed through myriad trajectories of different cultures/ages, becoming through his works, a site of cultural contestation. Hamlet, the eponymous protagonist of the tragedy 'Hamlet', was almost the tragedian's doppelganger, created at a critical juncture in his personal life. This paper looks at the diverse interpretations of the play, to map a transformation from the local to the global and vice versa. Taking the conventional representation of Hamlet by Kenneth Branagh in his 1996 film adaptation as a frame of reference, it examines two other versions of Hamlet, the absurdist, meta theatrical experiment; 'Hamlet: The Clown Prince', directed by Rajat Kapoor and the musical, a Stockhausen media production of 2007, 'Hamlet in Rock'.
\end{abstract}

Keywords: Adaptation, Eurocentrism, Post-Colonial, Absurdist, Rock

\section{Introduction:}

He was the man who of all modern and perhaps ancient poets, had the largest and most comprehensive soul. But Shakespeare's magic could not copied be; within that circle none durst walk but he. He was naturally learned; he needed not the spectacle of books to read nature. He looked inwards, and found her there.

John Dryden 
Hamlet's experience simply could not have happened to a plumber.

\section{George Bernard Shaw}

That William Shakespeare could function as an exhibit to entice onlookers is perhaps an established fact, as is pointed out by Clare Pettitt whilst analysing the spectacle of the Great Exhibition of 1851 where Shakespeare was indeed the show-stopper; 'In the British Nave of the Crystal Palace, sandwiched between an "Improved open fire pedestal stove, with candelabrum for gas" by W. Bailey \& Sons and an "Ornamental rustic dome of cast-iron, bronzed, 20 feet in diameter by 30 feet high"; and some "Garden- seats, [and] chairs" by the Coal brook Dale Company, visitors to the Great Exhibition of 1851 would have found exhibit number 83, listed in the Official Catalogue as “Unfinished statue of Shakespeare, from the Stratford bust" by John Bell' (Marshall and Poole, 61). In this context Paul A. Kottman reminds us how the Shakespearean Canon has managed to generate persistent scholarly curiosity throughout decades; "The phrase "Shakespeare Cult" is often used to describe the intense attention paid by German writers and philosophers to Shakespeare's drama- starting specially, with writings by Gotthold Ephraim Lessing (1729-81), Johann Gottfried Herder (1744-1803) and Johann Wolfgang Goethe (1749-1832), extending to writings by Friedrich Schiller (1759-1805)....For Herder, a key figure in this movement, to engage Shakespeare is to better grasp one's own historical situation - rather than the other way around' (Wells, 241). Elaborating further on the relevance of Shakespearean scholarship in contemporary times, Kottman explains, "The "Cult" of Shakespeare itself grew out of a deep sense of the historicity of Shakespeare's work, and of artistic practices generally - just as they sought to highlight in Shakespeare's works an occasion for us to become more historically self-aware' (Wells, 257). Shakespeare's oeuvres have been widely proliferated through institutionalization of Western humanities in the colonies. The establishment of an independent Shakespearean Canon kept the interest flowing over the years often overshadowing conspiracy theories regarding the authorship of his work. For us in the colonies, the English handed us 'their' Shakespeare with its connotative virtues of Humanism, Eurocentrism and Universalism. Debating the institutionalization of English literary studies, Gauri Viswanathan while urging scholars to not downplay the severity of cultural hegemony operational from the early days of the British Raj, outlines the role curriculum played, 'The curriculum is conceived here not in the perennialist sense of an objective, essentialized entity but rather as discourse, activity, process- as one of the mechanisms through which knowledge is socially distributed and culturally validated' (Vishwanathan, 3). Therefore if Shakespeare is a cultural signifier functional through western discourse, it is indeed crucial to challenge and deconstruct the bardic tradition with counter discursive articulations. However subverting the Shakespearean canon does not mean substituting one set of reading practices with another because the very idea of canonicity is inbuilt in curriculum, academia and in the publication industry. Angele Eward Mangione in her analytical research work based on studying Shakespeare from a position of postcoloniality, states the need 'to decolonize Shakespeare by dismantling the deep-seated, prejudicial ideologies of race, gender and colonialism that are evident in British drama such as Shakespeare's, and which have shaped the lives of millions of people who encountered Shakespeare through colonial education. On a personal level, these postcolonial writers recognise and expose the role 
that English Literature played in disseminating dichotomies such as centre/margin, centre/periphery, canonical/uncanonical and civilized/uncivilized' (Mangione, 148).

One of the best adaptations of William Shakespeare made in recent times is by Indian film maker Vishal Bhardwaj whose 'writing back' to Shakespeare birthed the trilogy - Maqbool (2003), Omkara (2006) and Haider (2014). Bhardwaj's adapted Shakespearean characters forayed into a disquieting world of domestic politics, sometimes staging their act in contested political territories like Kashmir or re-enacting a cautionary tale of love and betrayal in the outlandish backdrop of Uttar Pradesh, rife with mafia politics. Deconstructing Shakespeare by attempting to challenge the interior colonialities of a sovereign state or stoking the underbelly of the dark corridors of power and violence has almost inevitably made Vishal Bhardwaj's adaptations more than mere cultural translations. This paper makes an effort to scrutinize whether it is possible to embroil in a cultural politics of resistance through an effective coup de théâtre; Rajat Kapoor's 'Hamlet: The Clown Prince' and the 2007 musical 'Hamlet in Rock' would be cases in point.

Exploring the idea of Shakespearean appropriation, Julie Sanders points out how; 'The adaptation of Shakespeare invariably makes him 'fit' for new cultural contexts and political ideologies different from those of his own age. As a result, a historiographical approach to Shakespearean appropriation becomes also in part a study of theoretical movements; many theories which have had their intellectual foundation in recent decades, such as feminism, postmodernism, structuralism, gay, lesbian and transgender theory, post colonialism and now, increasingly, the new digital humanities, have all had a profound effect on the modes and methodologies of adapting Shakespeare' (Sanders, 58). However, She also insists us to be mindful of the fact that 'Shakespeare was himself an adapter and imitator, an appropriator of myth, fairy tale, folklore, the historical chronicles of Holinshed, and the prose fiction and poetry of his day, as well as classical texts by Ovid and Plutarch' (Sanders, 59). Debating further the contemporaneity of Shakespeare, Sanders highlights the commercial viability of Shakespearean scholarship; 'His global currency in recent decades seems to further fuel that adaptability, recognizable as his 'brand' is in Asia, Latin America, West Africa and elsewhere. There are also undoubtedly economic and legal factors at play: Shakespeare is helpfully outside copy-right law, making him both safe and cheap, as well as fascinating, to adapt. And adaptation as an art, as we have already seen, feeds other adaptations, so the 'Shakespeare industry' is a self-generating force in this regard' (Sanders, 60).While suggesting that any hint at 'participatory reading' would involve 'intertextuality, and its specific manifestation in the form of adaptation and appropriation' (Sanders, 1), she further outlines how 'appropriation carries out the same sustained engagement of adaptation but frequently adopts a posture of critique, overt commentary and even sometimes assault or attack' (Sanders, 6). In this context of cross-reading, the concept one refers to is, 'Pastiche', another term of French derivation which is often assumed to have a satiric undertow or a parodic intention' (Sanders, 7). This paper demonstrates that Rajat Kapoor directed, 'Hamlet: The Clown Prince' though is an appropriation of a canonical text within the theatrical dimension, however imbibes elements of parodic subversion which shares certain aspects of a Pastiche. Its fragmented and eclectic playfulness is vividly reminiscent of the postmodernist form; Pastiche. This paper also tries to explore how certain art 
forms can dismantle established literary canons and allows new improvised versions of conventional textual tradition to shape itself. The musical rock version of Hamlet that is composed entirely on mixing Shakespearean dialogues with lyrical symbolism of electronic rock music is an interesting example of how intertextuality and cross-fertilized readings operate in literature.

\section{Hamletian Dilemna- A Classic Catch-22 Situation for Interpreters of the Play-Text?}

To be or not to be: that is the question:

Whether 'tis nobler in the mind to suffer

The slings and arrows of outrageous fortune,

Or to take arms against a sea of troubles,

And by opposing end them?

Hamlet $(3.1 .64-98)$

The story of Hamlet, a young prince who comes to set things right after his native kingdom of Denmark is in a stage of topsy-turvy Dom but ends up becoming a sort of agent provocateur caught up fighting his own demons is almost a cult in its own right. The play has always stirred popular imagination with suggestions of procrastination and inertia. Some critics like David Bevington consider Hamlet's humanity as a potent factor for his incapacity for action, 'Shakespeare's way of humanizing his revenger is to present a Hamlet who is thoughtful, introspective, witty, capable of enduring friendships, deeply moved by the need for human affection both in his family and in romantic attachments, and philosophically inquisitive' (McEachern, 60). He points out that this 'internal conflict, in which civilized decency is posed with seemingly irreconcilable opposition against the need for brutally direct action, is the stuff of tragic greatness' (McEachern, 61). The reason why Hamlet is in itself a canonical work lending contingency to subsequent adaptations, is because of its depiction of a world-weary protagonist (carrying the modernist tag of Weltschmerz) and with an almost postmodernist approach in his anti-heroic existential world view. If William Shakespeare, the bard, is 'of all ages' then Hamlet, surely, is 'of all cultural and temporal frames'. Some critics label the play religious as it represents a stereotyped Christian struggle; it is at the same time almost a morality play exposing the element of conflict hidden in a human soul. Hamlet, non-committal in his cause, cannot bring himself to kill Claudius - the probable murder a narrative and theatrical ploy that may have resolved all contradictions to ensure a smooth cathartic end. Gail Kern Paster while critiquing the play, points out that Hamlet's 'efforts to change himself and his situation take the indirect form of putting on a play. The depressed prince requires the mimetic actions of others - professional players uninvolved in the political crisis and merely eager for patronage - to stimulate himself and Claudius into direct confrontation' (Wells, 157). Colin Burrow explains, that compared to other tragic characters, 'Hamlet by contrast persuades himself to "act" in the theatrical rather than the practical sense, by staging his play designed to "catch the conscience of the king"' (McEachern, 16). This mix of 'play' and 'reality' which characterises Hamlet's 'playfulness' makes the tragedy profoundly representational, performative and translatable, particularly in terms of theatre or stage. The dilemma of course is persistent: whether there should/could be a generic transformation; can Hamlet be represented as a buffoonish character or a 
modern man dealing with his angst? Interpreters of Hamlet have always found themselves in a tricky catch-22 situation, plagued with a difficult choice to make, in appropriating the play: total metamorphosis of the canonical work or resembling the hypo text? Which should be the ideal reception? Julie Sanders draws a list of reasons behind Hamlets canonical standing; 'Ophelia's tragic trajectory has proved of considerable interest to feminist adapters, male and female alike, Angela Carter's novels and short fiction are haunted by the image of Ophelia, often filtered through subsequent adaptational gestures, not least Pre-Raphaelite painting and cinematic interpretations. If feminism has found relational associations with Hamlet in more recent decades in the early 20th century, it was the work of Sigmund Freud and the influence of theories of psychoanalysis that placed the play at the heart of the literary canon. As the exploration of a mind in crisis, the play attracted numerous commentators and respondents, not least T.S. Eliot, whose essays and wider interest in this area proved influential both in the shaping of the canon and in the discipline of English literature itself' (Sanders, 66). When it comes to the question of the performance and staging of the play, 'One factor that has amplified and extended the canonicity of Hamlet is that the prince of Denmark has come to be regarded as the culminating role for any aspiring young actor. It serves as a career touchstone as much as a literary one. The "actor of the day" is almost obliged to engage with the role in some format: in the 20th century Sir John Gielgud, Sir Laurence Olivier, Richard Burton and Kenneth Branagh among them' (Sanders, 67).

\section{Branaghian Hamlet- a Shadow of Eurocentrism Behind the Mix of Melancholy and Bravado?}

According to Britannica, Kenneth Branagh, an actor-director born in Northern Ireland, is 'credited with making Shakespeare accessible to the masses'. He adapted several Shakespearean plays on stage and onscreen with precision and creativity. Britannica mentions that one of the peaks of his career was in 1984 when he joined the prestigious Royal Shakespeare Company which provided him an opportunity to garner acclaim for playing Hamlet and Henry V. Critiquing the film version of Hamlet (1996) in which Branagh played the eponymous protagonist, Roger Ebert comments, 'His Hamlet is long, but not slow, deep but not difficult, and it vibrated with the relief of actors who have great things to say and the right ways to say them. And in 70-mm. version, it has a visual clarity that is breath taking. It is the first uncut film version of Shakespeare's most challenging tragedy...Branagh's Hamlet lacks the narcissistic intensity of Laurence Olivier's (in the 1948 Academy Award winner), but the film as a whole is better, placing Hamlet in the larger context of royal politics, and making him less a subject for pity' (슬er). Ebert praising 'Branagh's visual showmanship', emphasises on the actor's histrionics, 'In all of his films, he reveals his joy in theatrical gestures' and this, Ebert believes, is one of the turning points of this uncut Hamlet, 'the crucial role of the play within the play. Many productions reduce the visiting troupe of actors to walk-ons; they provide a hook for Hamlet's advice to the players, and merely suggest the performance that Hamlet hopes will startle Claudius into betraying himself' (Roger). What Roger Ebert suggests is that Kenneth Branagh's fundamental directorial move was making the play within the play primary, further pointing out how Branagh devised certain key moments in an extraordinary light, for example, 'how Hamlet's most famous soliloquy (To be or not to be....) is delivered into a mirror, so that his own indecision is thrust back at him'. In spite of the 
overwhelming reception that Branaghian Hamlet received, my argument is a tad critical. The play in its cinematic form may have displayed certain spectacular innovations but one may argue that it still remains an old wine served in a new bottle. The Branaghian Hamlet retains the authenticity of an Elizabethan/Danish protagonist whose experience of moral crisis, free will and choice is emblematic of a Eurocentric world view. It is Hamlet, the white European male born out of Renaissance learning, moved by Christian ideas of salvation, redemption and damnation, acting autocrat-like as a patriarch and ending up doing more damage to the rotten state of Denmark than anticipated. It is acutely disappointing that Branagh does not use his Irishness to toy with the thematic content of any Shakespearean play, including Hamlet, but rather sustains the same Eurocentric model rooted in western colonial framework. Branaghian Hamlet (like the Shakespearean original) returned to colonise his enemies, the women he loved but finally disintegrated into insanity while failing to colonise his own 'heart of darkness'. That Branagh could not transform into a James Joyce, is, again, a matter of choice on the part of the interpreter. If Branagh's Hamlet represents the universalistic principles of Shakespearean experience, as a Globalised concept, it is also, at the same time, very 'British' and 'European' born out of a specific historicity: Renaissance Humanism. This Hamlet is predominantly Elizabethan and a Dane. Therefore what is perceived as global can also be an articulation of the local and regional.

\section{Deconstructing Hamlet - Towards a Metaphysics of Metatheatre: Rajat Kapoor's 'Hamlet-The Clown Prince':}

Some forms of adaptation focus on extracting a peripheral character from a canonical text and putting it under spotlight.

Tom Stoppard's 1967 play 'Rosencrantz and Guildenstern Are Dead' is one such instance of theatrical spectacle where two minor characters create an absurdist narrative deviating from the source text to re-define dramaturgy. Politically motivated renderings of Hamlet, aimed at filling in the gaps and fissures of the original, are not rare. It is a steady postmodernist concern to fracture the monolithic textual fabric of Hamlet in order to create alternate ideological spaces. The reader or spectator can play an active role in this act of 'reading of appropriative texts', which as Julie Sanders believes, 'is frequently involved in a process of reading between the lines, offering analogues or supplements to what is available in a source text, and drawing attention to its gaps and absences' (Sanders, 75). She deploys horticultural terms like 'Grafting' (Gerard Genette already employs this term in 'Palimpsests') to explain how a 'creative move is sometimes achieved by extrapolating a particular story line or character's trajectory from the original and relocating that to a new context, historical, geographical and/or cultural' (Sanders, 69). This is almost exactly what is illustrated through the Award winning Cinematograph production of Rajat Kapoor; 'Hamlet-The Clown Prince' which experiments with the stage, focuses on the idea of the 'play's the thing', breaks the fourth wall and engages with the audience to 'catch their conscience' in an almost Brechtian fashion. The action or inaction (Beckett like) begins with a group of clowns deliberating on staging the Shakespearean classic Hamlet with a comic intent to misinterpret, delete, edit or revise scenes to present their own improvised version in stylized gibberish, often in European languages (including 
English) instead of Colloquial English. The cast comprised of exceptional talents like Atul Kumar playing the lead, Neil Bhoopalam, Namit Das, Puja Sarup, and Rachel D'Souza has an approx. 90100 minutes running time during which the idea of metatheatricality is foregrounded in a disturbingly persistent manner. As a spectator you cannot avoid your eyes from darting across the stage: observing every move of the actors, the visual gigs, as actors not involved in any particular scene are nevertheless present on stage drawing attention through funny interactions with others off stage. Kenneth Kwok makes the following observation, 'There's everything from Keatonseque clowning to audience interaction; from straight forward slapstick to deadpan humour - for example when asked how one prepares for the part of Ophelia, an actor replies, "I'd take swimming lessons"...At one point a character says, "We are all going to die", then he points at a random member of the audience: "Even him". But, more significantly, against The Clown Prince's backdrop of mischievous tomfoolery, aspects of Hamlet can be presented straight so that they stand out in stark relief. The death of Ophelia is one scene that resonates powerfully as a result of this sudden isolation. Another is when the play closes around the actor playing Hamlet as he breaks the fourth wall and directly asks us, the audience, to actually stop and think what it would be like if we were to lose a loved one. Profound moments also come when comedy and tragedy are allowed to collide noisily: an actor questions why the company is staging Hamlet in the first place, bombastically proclaiming, "We are from India. There's enough tragedy in Asia"' (The Flying).The reviewer further points out how 'Atul Kumar as the actor playing Hamlet with his surface expression, always seems to have something hidden, something still unsaid that inscrutability gives his Hamlet a gravitas that is immensely compelling'(The Flying).

Shonali Muthalaly, a theatre critic, comments on the play's effort at creating a melange of 'tragic drama and slapstick humour' as rare in 'theatre space'. According to the reviewer, the play is spontaneous 'simply because it's been known to evolve right up onstage, in front of audiences' (The $\underline{\text { Hindu }})$. The critic continues, 'After all, not only are a bunch of clowns trying hard to interpret the drama-tragedy-and-angst-filled original text (sometimes misinterpreting it, sometimes excitedly dreaming up meanings that never crossed Shakespeare's mind, often hopelessly entangling everything) but they also choose to tell their story in gibberish, sprinkled with key phrases from the original play...In spite of all the goofing about, the actors are sincere about finding the essence of Hamlet' (The Hindu). In an interview with The Hindu, the director Rajat Kapoor confesses how clowning as a leitmotif in his creative thought, emerged with the silent American comedies of early 20th century, the Charlie Chaplin and Buster Keaton films. Critic Urvashi Vashist labels the play, a pantomime, truly representing, 'The poignant inner lives of these actors - pale-faced clowns suffering heart ache, huddled and whispering when not called upon to entertain - are unfurled in plain view, played out and upon by their fellows and by the audience; they are hidden only by the spectator's deliberate kindness, or inattention'(International Theatre). The review further exaggerates the idea that the 'seemingly impulsive patterns of movement seems largely a function of the distinctive, idiosyncratic choreography that specifies, marks and defines identities. Individuals with masked, painted faces are paradoxically, merely, "words, words, words", and through the gaudy reference points of motion, quintessentially themselves in silence' (International Theatre). Reviewing the play, Alfred Hickling points out that this theatrical piece balances itself on 
the actor playing Hamlet, 'Atul Kumar presents a madman prone to fits of sanity, while his virtuoso vocal improvisations - approximately $40 \%$ in English - borrow from the Vidhushaka, the colloquial fool of Sanskrit drama, and the Bollywood method of presenting the dialogue in several different languages at once' (The Guardian).

'Hamlet - The Clown Prince', is the first in the series of Shakespearean adaptations directed by Rajat

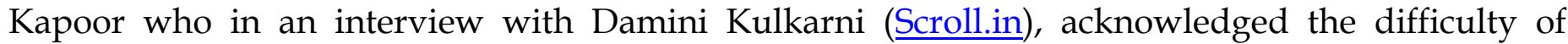
translating Shakespeare into contemporary theatre along with recognising his passion for fusing stand-up comedy with traditional theatre.

The play basically requires the audience to willingly suspend their disbelief (including their awareness of the source text), to instead employ pure imagination for this joyride of nonsensical humour. Most importantly, as the tomfoolery onstage engages the attention of the audience by dismantling the fourth wall, the play becomes an absurdist classic - reminding one of Beckettian and Pinteresque stage ideologies. The intricacies of Hamletian existential crisis could develop into a potent theme in absurd theatre, deploying metatheatrics to hint at a more sublime philosophy. It would be a fair judgment if one deduces that 'Hamlet - The Clown Prince' is strongly reminiscent of Brechtian epic theatre. Outlining the idea behind Epic theatre, Robert Gordon states, 'Brecht was interested in self-consciously retelling a story rather than realistically embodying the events of a narrative. His techniques encouraged the spectator to view the way in which playwright and actors presented the tale, exposing the mechanisms of theatre, and promoting an attitude of curiosity rather than emotional and empathic response to the acting typical of the naturalistic and expressionistic forms dominant in German Theatre at the time'. Kapoor's play uses some spectacular ploys of 'Verfremdungseffekt' (Brecht introduced it through unexpected interruptions in the flow of the narrative: change in lighting or break in dialogue) by drawing attention of the audience to the play's constructedness. According to Gordon, 'Verfremdungseffekt is a distancing device or defamiliarisation effect, that makes the everyday appear surprising in order to enable a spectator to interrogate each dramatic event rather than regard it as part of a 'natural order'....The cognitive disruption provoked by all of Brecht's techniques serves to alter the spectator's habitual way of thinking about the way things are'. The clown-cast of the play with painted visages and comic one liners are the major disruptions/interruptions onstage in the Brechtian sense, exposing the spontaneous improvisations that metatheatrical practices engage in. Moreover from a postcolonial vantage point, the play mystifies generic divisions (between comedy and tragedy) and through nonsense theatre subverts the canonical status of Shakespearean Hamlet which, as a ubiquitous presence in the curriculum of colonies, has long colonised the native mind. The very idea of a troupe of clowns deconstructing a Shakespearean classic, playing with the text but at the same time, enacting through their comedy an awareness of Death that underpins the original Shakespearean tragedy, is, in itself an unforgettable theatrical experience of our times. The play is 180 shows old debuting in around 2009 and has travelled extensively around the Globe. In the light of the above fact, one can presumably argue that a local expression can transcend transnational bounds to become globalised as a cultural product. The categories 'local' and 'global' are, perhaps, not adequate parameters to map such distinctive trajectories. 


\section{Hamlet as a Rockstar - Punk/Counter Culture's Claim over Hamlet:}

Will Straw, when trying to document the rise of Rock Culture, particularly Heavy Metal in the West in the 1970s, observes how rock music is 'heavily male dominated' and how 'The recurrence of black leather and "rebel" postures in the iconography surrounding such music', was decidedly masculinistic (During, 459). Straw explores the complexity of rock culture by pointing out how, 'certain types of rock (glitter, punk) accomplished important interventions in sexual politics' (During, 461). It demonstrates how certain motifs of rock music finds poignancy in Stockhausen Media production of 2007: Hamlet in Rock, which appears to be an excessive endeavour in valorisation of masculinity. The play which is an adaptation of Shakespearean Hamlet reinvented in a rock musical form has an interesting ensemble cast comprised of American and German actors, with Monika Muller and Rudolf Volz as creative and concept design heads. Before we move to the nuances of this reading of Hamlet, let us comprehend the musical in a nutshell. The stage designed by Peter Gric is minimalistic with a few wooden stairs and an elevated pedestal which serves as arena for important actions of the play; the coronation of Claudius, the murder of Polonius and for the staging of the play, 'The Mousetrap'. The musicians with their electronic guitars and equipment are seated onstage throughout the two hours of dramatic action. Unlike the traditional adaptations (including Branagh's), the musical does not begin with the visitation of the Ghost of Hamlet's father but rather with a song and a haunting refrain: 'All that lives must die'. The play employs all original Shakespearean lyrics, some of which are breathtakingly jazzy. Paul Miller, the actor playing Hamlet, appears onstage, dressed like a punkstar, all in black, almost a roadside junkie flaunting a unisex hairstyle, delivering stunning numbers like 'Hey get thee to a nunnery' which can seduce any rock fandom. However there may be certain complications in this musical dramatization which I wish to foreground; primarily, the gendered structure of the narrative framed by deployment of rock music which though may have counter hegemonic undertones and resonate with subversion of authority (that gives authenticity to the depiction of Hamlet and his melancholic disposition), yet sadly end up reinforcing gender stereotypes. From the very beginning Rock becomes a mode of male protest; Hamlet standing up against Claudius, Polonius, Laertes, Gertrude and Ophelia exhibiting an extreme form of hyper-masculinity, bordering on themes of sexual lapse, betrayal and adultery as a 'feminine thing'. The song, 'Frailty thy name is woman', performed with rage and vigour true to that of a rock performer, demonstrates how rock can operate to symbolise male prowess. This musical combines the masculine power of rock with Shakespearean tragic philosophy to represent a brutal world of patriarchy where Women are relentlessly persecuted for their sexual excesses. Like any play of Harold Pinter, the women characters onstage become vessels of male resentment in the form of violent outpourings of rock music while the women are assigned soft, flowery numbers. The machismo of Rock becomes a gender referent in acting as a touchstone of heteronormativity where any traces of emotional weakness or effeminacy of the hero is dissolved through hard-hitting powerful rock music. Therefore violence in music and theme works in tandem to celebrate the true form of male liberty. The Hamlet of 'Hamlet in Rock' who begins as a fainthearted, foppish, dandy like character rediscovers himself during the action onstage, through rock music, to evolve into a homophobic and misogynist maniac. 


\section{Conclusion:}

We can say of Shakespeare that never has a man turned so little knowledge to such great account.

T.S. Eliot

This paper attempts to explore how diverse readings and performance of Shakespeare can dismantle the elusive categories of 'local' and 'global' along with demonstrating how local interpretations are globalised just as global products are historically born out of local particularities. The reason why William Shakespeare's popularity never wanes is because of the malleability of his art and the timelessness of his thematic content. In this paper, Kenneth Branagh's 1996 cinematic adaptation of Hamlet was a reference point, a parameter of Eurocentrism against which two other adaptations of Hamlet were weighed, Rajat Kapoor's Serio-Comic, 'Hamlet -The Clown Prince' and Stockhausen Media production of 2007, 'Hamlet in Rock'. These two appropriative interpretations of Hamlet transform generic divisions to present Hamlet with a new twist; while the musical 'Hamlet in Rock' challenge the divide between high and popular culture, Rajat Kapoor's Hamlet presents an absurdist version of a soul caught in moral crisis. It is undeniable that any adaptation of a canonical work helps exaggerate the relevance of the canon and often adds to its perpetuation. The interest surrounding Shakespearean canon and its subsequent readings could neither be just a global or local phenomena but rather mystifies the distinctions between the two in a transnational context wherein an Asian production can reach a Global audience while, what is considered universal or global can remain sadly, parochial in its Eurocentric concerns. One must acknowledge that Hamlet, as a thinking subject was born out of a specific historicity and epistemological quest and its germination is narrowly rooted in a certain period of History. Likewise, any local enunciation is a result of the confluence between regionalism and globalism. The only question that this paper may not have answered satisfactorily is whether such a flux of Shakespearean adaptations can dismantle or perpetuate the canon, for the simple reason that it is, perhaps, an ongoing continuum.

\section{References}

Ebert, Roger. "Hamlet Movie Review \& Film Summary." Rogerebert.com. N.p., 1997. Web. 16 June 2021. <https://www.rogerebert.com/reviews/hamlet-1996>.

Eward-Mangione, Angela. "Decolonizing Shakespeare: Race, Gender, And Colonialism In Three Adaptations Of Three Plays By William Shakespeare." Doctor of Philosophy (Ph.D.). University of South Florida, 2014. Print.

Gordon, Robert. "Brecht, Interruptions And Epic Theatre." The British Library. N.p., 2017. Web. 14 Apr. 2021. <https://www.bl.uk/20th-century-literature/articles/brecht-interruptions-and-epic-theatre>. 
Hickling, Alfred. "Hamlet The Clown Prince - Review." The Guardian 2011. Web. 20 Apr. 2021. <https://amp.theguardian.com/stage/2011/mar/09/hamlet-the-clown-prince-review>.

Shakespeare, William. Hamlet. Auckland, N.Z.: Floating Press, 2008. Print.

Stockhausen Media Production. Hamlet In Rock. 2007. Web. 16 Mar. 2021 $<$ https:/ / www.youtube.com/watch?v=aXNlxjJqCgo>.

Bevington, David. "Tragedy in Shakespeare's Career." The Cambridge Companion to Shakespearean Tragedy. Ed. Claire McEachern. Cambridge: Cambridge UP, 2013. 51-70. Print.

Burrow, Colin. "What Is a Shakespearean Tragedy?" The Cambridge Companion to Shakespearean Tragedy. Ed. Claire McEachern. Cambridge: Cambridge UP, 2013. 1-22. Print.

Britannica, The Editors of Encyclopaedia. "Kenneth Branagh". Encyclopedia Britannica, 26 May. 2021, <https:/ / www.britannica.com/biography/Kenneth-Branagh. Accessed 7 July 2021.>

Kottman, Paul. A. "Why think about Shakespearean tragedy today?" Cambridge Guide to Shakespeare Studies, edited by Stanley Wells, Cambridge University Press, 1986. Print.

Kulkarni, Damini. "Hamlet: The Clown Prince. Imbuing sombre Shakespearean characters with joviality and colour". Scroll.in. 14 Dec. 2016. Web. 25 Apr. 2021. <https://amp.scroll.in/article/822110/hamlet-theclown-prince-imbuing-sombre-shakespearean-characters-with-joviality-and-colour>.Accessed 14 April 2021

Kwok, Kenneth. "The Comedy of the Tragic Clown". The Flying Inkpot.com. 26 Nov. 2009. Web. 25 April. 2021. <https:/ /inkpotreviews.com/2009reviews/1126, haml, kk.xml>.Accessed 14 April 2021

Muthalaly, Shonali. "Bring on the Clowns: Hamlet - The Clown Prince". The Hindu. 7 Nov. 2016. Web. 24 Apr. 2021. <https://www.google.com/amp/s/www.thehindu.com/features/friday-review/theatre/Bringon-the-clowns-lsquoHamlet-mdash-The-Clown-Princersquo/article11632648.ece/amp/>. Accessed 14 April 2021

Paster, Gail. K. "The tragic subject and its passions". Cambridge Guide to Shakespeare Studies, edited by Stanley Wells, UK: Cambridge University Press, 1986. Print.

Pettitt, Clare. "Shakespeare at the Great Exhibition of 1857". Victorian Shakespeare Vol 2 Literature and Culture, edited by Gail Marshall and Adrian Poole, London: Palgrave Macmillan, 2003. Print.

Sanders, Julie. Adaptation and Appropriation. London and New York: Routledge, 2016. Print.

Straw, Will. "Characterizing Rock Music Culture: The Case of Heavy Metal." Cultural Studies Reader, edited by Simon During, Routledge, 1999. Print.

Vashisht, Urvashi. "Hamlet". Plays to See International Theatre Reviews.com. 25 Mar. 2011. Web. 25 Apr. 2021. <https:/ / playstosee.com/hamlet-clown-prince/>.Accessed 15 April 2021

Viswanathan, Gauri. Masks of Conquest Literary Study and British Rule in India. UK: Oxford University Press, 1989. Print. 
| Purbali_Sengupta has completed her in English and French Literature from Visva Bharati (2002) and received training in 5 European languages from Folkuniversitet, Stockholm. Worked as Interpreter and language instructor in Stockholm for 4 years. Have worked as an Assistant Professor in English and French Literature at School of liberal arts and culture studies, Adamas University, Kolkata for 3.5 years. Presently teaching French at a Management school in Kolkata. Books and Cinema are passions. 